According to SAGE author sharing guidelines this article is authors accepted version. Article is First Published Online February 10, 2019 European Educational Research Journal, 2019, 1-19, https://doi.org/10.1177/1474904119827462

\title{
Characteristics of educational sciences research activity in European post- socialist countries in the period 1996 to 2013: content analysis approach
}

\author{
Dejana Bouillet ${ }^{\mathrm{a}, *}$ \\ Maja Jokić ${ }^{b}$ \\ ${ }^{a}$ Faculty of Teacher Education, University of Zagreb, Savska 77, 10000 Zagreb, Croatia \\ dejana.bouillet@ufzg.hr \\ *corresponding author \\ ${ }^{\mathrm{b}}$ Institute for Social Research in Zagreb, Amruševa 8, 10000 Zagreb, Croatia \\ maja@idi.hr
}

\begin{abstract}
:
In European post-socialistic countries or more commonly known as Central and Eastern Europe (CEE) countries, regardless of their differences and specifics, the common communist and post-communist legacies in the field of educational sciences are still recognizable. The aim of this paper is to explore research activity in the educational sciences in 15 CEE countries: 11 EU member states and 4 former Yugoslav Republic in the period from 1996 to 2013. The purpose of this research is to recognize the specificity and dynamics of subject and content issues, and development of methodological approaches in the educational science research. The sample consists of abstracts 2,395 papers by CEE authors published in 265 journals indexed in Scopus between 1996 and 2013. Content analysis was applied, where the abstracts were grouped into specifically created categories describing the content and methods of the paper and analysed on the basis of two criterion variables - CEE and non-CEE or international journals. The $\chi^{2}$ test showed that the field of educational sciences in 15 European post-socialist countries changed over time in terms of quantity, content, and methods, becoming more expansive and diverse, which is recognisable both in papers published in international and in CEE journals.
\end{abstract}

Keywords: educational science thematic research, content analysis, peer review journals, European post-socialist countries (CEE) 


\section{Introduction}

European post-socialistic countries, usually called the Central and Eastern Europe (CEE) countries have gone through significant structural, economic and social changes since their independence in the 1990s and the transformation of their social order. Although the CEE, because of their common socialist legacy is often discussed as a group of countries, most of them have its own peculiarities (Proteasa et al., 2017; Tarlea, 2017). In this respect, Radó (2011) emphasizes that explaining social processes on the basis of the common heritage of post-socialist European states is no longer a promising and founded approach. Other authors do not entirely agree with his opinion. According to Dobbins "the higher education (HE) systems of CEE have been influenced by a bewildering array of internal and external forces of change in the past 25 years: the introduction of market economies and democracy, the renewal of the academic profession, public sector reforms and, not least, the Europeanization and internationalization of $\mathrm{HE}$ have penetrated to the core of pre-existing governance arrangements and regulatory frameworks" (Dobbins, 2017, p. 684). Kwiek (2012) stressed that the influence of the socialist social structure in the countries concerned is still recognisable, especially in terms of the relatively poor interest of decision-makers in scientific research and educational reforms, which is negatively reflected in the competitiveness and international visibility of the scientific achievements of the region. Although post-socialist higher education systems have different roots, communism standardized those (Kováts et al., 2017) by tight state control, bureaucratization and the role of communist ideology in the governance of higher education affairs (Antonowicz et al., 2017). Kováts et al. (2017) stressed that after the change of regime, the allure of European integration put many post-socialist countries on a similar path, even if the pace of change was different in some countries. These arguments justify our selection of CEE as a group of countries with the common historical legacy which influences the Europeanization process of educational sciences. The published results concerning research issues of educational sciences of CEE countries, as a group of more than $10 \mathrm{EU}$ member states and related historical and socio-economic legacy, are relatively low (Lindblad, 2014).

Either way, conclusions about the specificity of any science, including educational sciences, can be made by analysing scientific papers published in academic journals, which have a significant role in any scientific discipline. Journals offer scientists a forum for communicating scientific achievements, ideas, discussions, exchange of information, and accumulation of knowledge gained within a particular field (Nolen, 2009; Eğmir et al., 2017). Journal articles are a suitable source of empirical analysis of research output, as they reflect results, emergence and impact of research (Aman and Botte, 2017). The methods, goals, content, and other components of papers published in journals indicate the significance of certain research topics, the dominance of certain scientific and theoretical paradigms, as well as other aspects of scientific activity. A suitable research method for the scientific discipline itself is content analysis, understood as a research method of the objective, systematic, qualitative, and quantitative description of the meaning, content, and intentions included in a particular communication message (Prasad, 2008). A content analysis of scientific journals is 
an important indicator of the current knowledge and empirical practice in a scientific community.

In this paper, the educational sciences are considered as a scientific discipline that enriches the practice of learning and teaching with a wide corpus of specific knowledge, developing and forming educational theories and methods (Kalantzis and Cope, 2012) with the aim of contributing to the quality, effectiveness, innovation, and purposefulness of educational practices and policies (Wubbels, 2016).

The aim of this paper is to examine research activity in educational sciences of $15 \mathrm{CEE}$ countries that share the common historical legacy, with the purpose of understanding the specificity and dynamics of subject and content issues, and development of methodological approaches in the discipline. In this paper, we shall try to establish whether that is indeed the case by analysing the abstracts of papers of scientists from post-socialist countries published in peer review journals indexed in the Scopus database from 1996 to 2013. The analysis is aimed at finding answers to two research questions:

- Have there been changes in the subject issues and methods of scientific papers in the field of educational sciences by scientists from 15 European post-socialist countries over time and, if so, how are they manifested?

- Have there been changes in the subject issues and methods of scientific papers in terms of whether their papers were published in international (non-CEE) journals or in domestic (CEE) journals?

The research tests the hypothesis that the field of educational sciences in 15 European postsocialistic countries has changed over time in terms of quantity, subject issues, and methods, becoming more expansive and diverse, which is equally recognizable in papers published in international and in CEE journals. The hypothesis arises from the conclusions in recent literature that indubitably show ongoing progress in educational sciences in modern societies (Manzon \& Bray, 2008; Manzon, 2018).

According to the available literature sources, this research is one of the first dealing with the content analysis of articles from 15 European post-socialist countries, published in peer review educational sciences journals indexed in the Scopus database.

\section{Literature review}

Literature in the field of educational sciences points to the very complex and multidimensional nature of the connection between research and education (Osler, 2013; Németh, 2017), which is reflected in the difficulty in defining clear and measurable research quality indicators in the field. Keiner and Hofbauer (2018) highlight a diversity of research on education in European counties, including different speeds and directions of research on education, as well as epistemologically different forms and modes of knowledge, different disciplinary cultures, cognitive textures and languages, different concepts and methodological standards and criteria for scientific quality etc. It is obvious that the concept of educational sciences, due to its complexity, is not coherent in Europe. Differences in approaches to the educational sciences and researches can cause conflicts among variety of disciplines (De Corte, 2018), as well as among different scientific paradigms and fields of research on 
educational phenomena (Fritzell, 2006). These difficulties are highlighted in the book Disciplines of Education: Their Role in the Future of Education Research (Furlong and Lawn, 2010) where authors elaborate that structural, historical and institutional factors affect all scientific fields in different ways, but in education their impact is quite profound.

However, "educational sciences are strongly articulated to international debates on education and they have to justify their assumptions and findings, often still embedded in local traditions, in taking into account discourses coming from outside" (Hofstetter and Schneuwly, 2002, p. 19).

Kalantzis and Cope (2012) position educational sciences as a metadiscipline, i.e., the discipline of all disciplines, since knowledge and education are the foundation stone of all sciences. In general, research of education has various forms and directions. Elken and Wollscheid (2016) differentiate between focus on pupils and teachers, subject and content issues and processes. According to Research Review Pedagogics and Education Science conducted by QANU (2013, p. 17), "recurrent themes of the educational research are: effects of learner characteristics, educational interventions, and school and contextual factors on preschool and school learning and learning at the workplace; diagnosis and education of children and other people with various kinds of disabilities; classroom interaction; teaching and learning in specific curricular domains; teaching and teacher education; educational technology and educational assessment; educational innovation and school leadership." Berliner (2002), in his commentary on educational sciences, points out that it is the most complex field of the social sciences since educational processes are affected by a very large number of mutually connected circumstances and conditions that indubitably diminish opportunities for generalizing the findings of research. At the same time, research in educational sciences over the past decades has experienced strong expansion, where scientific knowledge of education has become the foundation for planning educational policies and effective educational practice (Fritzell, 2006). Still, socioeconomic research shows that society affects education more than education affects society, although "education is regarded as a relatively autonomous system, the outcomes of which should have a decisive effect on the direction and dynamics of social development" (Pastuović, 2012, p. 50). All of these claims are in favor of interdisciplinary nature of educational sciences. According to Terhart (2017) interdisciplinary fields are rather fluid, they are open to impulses from outside (politics, administration, society) or inside the academic world (newly entering disciplines, theories, etc.) and give rise to new specializations. There is constant theoretical and methodological import and export, a blending of problems and themes (p. 924).

Although many scientific disciplines participate in the implementation of education, and educational sciences are interdisciplinary by nature, the strong interdependence between society and education constitutes a foundation that justifies the consideration of educational sciences as a field of the social sciences (Bellmann and $\mathrm{Su}, 2017$ ).

Some of the following researches could illustrate complexity and diversity of educational science field. On the basis of a content analysis of 758 papers published in six journals from 2003 to 2007, Nolen (2009) concluded that there was consensus on the subject matter and content of educational psychology. Little, Akin-Little \& Lyoyd (2011) analysed the content of the journal School Psychology International from 1990 to 2011 and concluded that the 
content of the published papers was not sufficiently in line with the usual classifications of the subject of school psychology, since more than a third of the papers published related to topics that are not represented in the used classification.

The most frequently used keywords in education research, according to Çiftçi et al. (2016), are teachers, student, education, primary education, and learning. They used a sample of 7,681 articles published in 32 different journals. The authors focused on scientific publications in the educational sciences in Turkey from 2005 to 2014. Aussems et al. (2011), in their research on quasi-experiments in various social sciences (criminology, sociology, psychology, education), by analysing the content of journals published in 2002 and 2003, concluded that quasi-experiments were mostly used in educational sciences, while somewhat less in criminology, and very rarely in psychology and sociology. The authors also demonstrate a significant share of research in educational sciences based on convenience samples, especially in terms of the verification of educational methods, reducing the possibility to generalize the findings obtained in the pre- and post-testing of research participants.

Among the significant research concerning educational sciences development, mainly comparisons of two or more CEE countries are papers of Grimaldi (2015), Antunes (2016), Kushnir (2016), Antonowicz et al. (2017), Dakowska (2017), Dobbins (2017), Dobbins and Kwiek (2017), Kováts et al. (2017), Proteasa et al. (2017), Tarlea (2017). In general, it is possible to conclude that social changes, democratization, and the new political direction that marked education in European post-socialistic countries in the late 1980s and early 1990s are also evident in educational sciences. In that regard, for Walterová (2008) the 1990s are linked with the strengthening of the significance of comparative studies in Czech journals that deal with educational problems, innovations, and trends. They were mostly, however, descriptive in character and they mostly dealt with the structure of higher education. At the time, the topics of research mostly arose from projects aimed at problems in the national educational system or projects initiated from within the international community. Popov (2008) writes about the disintegration of the communist regime in Bulgaria that significantly contributed to changes in all spheres of civic life in Bulgaria. He states that the "subsequent years, in education, just like in other sectors, were filled with hopes, contradictions, and disappointments" (p. 272), and that the impact on education was characterised by "freedom, confusion, and powerlessness" (p. 273).

Although Bulgarian researchers at the time experienced freedom as they could independently choose the whats, hows, and whys of their research, they still had to face financial difficulties just as in the previous period. Popov (2008) mentions academic mobility as the basic characteristic of education and educational sciences in that historical period, which was visible in the strong international component of papers published in the domain.

Kuźma (2008) is of a similar opinion. He states that the transition from the socialist to the capitalist social structure in Poland had two mutually opposing effects, or tendencies, on education. The first relates to support of the "national educational system based on tradition and patriotism, expansion of the national heritage and culture, returning to traditional Christian values. The other tendency, known as liberalism, favours European integration processes, international contacts, supranational education and systems of research based on 
European human values" (p. 280). In Croatia, changes in education began later than in other transitional countries, while the shift in the direction of the development of the national curriculum from a traditional, content-oriented curriculum to a curriculum oriented towards pupils' achievements and the development of competences necessary for life and work in modern society is still pending (Baranović et al., 2013).

However, Keiner and Hofbauer (2018) agreed that there is not a lot empirically and systematically collected knowleadge about scholarly discourses and research practices in the filed of the educational science because of lack of evidence about conditions and practices of educational research knowledge production, distribution and reception within the CEE countries in a comparative perspective.

\section{Research method}

\section{Defining the sample}

The sample for this research is part of a larger, specially-created database to investigate the scholarly communication, visibility and development of social sciences research in 15 European post-socialistic countries. The sample was extracted from the dataset of bibliographic records of articles $(n=35,501)$ by authors from 15 European post-socialistic countries published in peer review social sciences journals $(n=2,726)$ indexed in Scopus database in the period 1996-2013. Among the countries analysed, eleven are members of the European Union (Bulgaria, Croatia, the Czech Republic, Estonia, Hungary, Latvia, Lithuania, Poland, Romania, Slovakia and Slovenia), and four of them (republics of the former Yugoslavia) have the status of candidate country for EU membership (Bosnia and Herzegovina, Serbia, Montenegro and Macedonia).

Scopus database has been chosen because it is the largest searchable citation and bibliographic source of literature for multidisciplinary scientific literatures (Bar-Ilan, 2007; Falagas et al., 2008; García et al., 2011; Chadegani et al., 2013), which is continually expanded and updated including retroactive inclusion of sources and citations. Scopus is more appropriate for the bibliometric analysis of social sciences than the Web of Science (WoS). As argued by Archambault et al. (2009), Moed et al. (2013) and Abadal et al. (2015), Scopus offers, thematically and regionally, a more balanced representation of journals and possesses credible journal selection procedures and adequate bibliometric indicators. According to Grančay et al. (2017) the CEE social scientists rely heavily on publishing in national regional journals and they warn of high instability of these journals in the WoS. Recently, Scopus is a database that makes the scientific work in CEE countries most visible, in comparison with other international sources. Furthermore, we have taken into account that papers indexed in Scopus count as relevant in career promotions as well as in international university rankings.

The period 1996-2013 has been defined by the project (whose details are in the Funding Acknowledgment) within which this research is carried out. The 1996 year is taken as the year that is the first year covering publications in Scopus. The ending year is 2013 because the project proposal was applied in 2014. 
For the purposes of this research, we adapted the Croatian classification of social sciences which is based on the OECD Frascati Field of Science (FOS) ${ }^{1}$ classification, containing the following scientific fields: Economics and business, Educational sciences, Information and communication sciences, Law, Political science, Psychology, Sociology, and three multidisciplinary fields: Social sciences, Social sciences and humanities, and Social sciences and other fields. Social science journals $(n=2,726)$ were re-classified by experts for each scientific field on the basis of a detailed insight into the purpose and problems specific to each of the journals analysed.

The sample for this research, 2,395 (or the share of $6.7 \%$ of the total sample for all social science) papers were published in 265 journals. With regard to the research questions, journals were divided into the two groups: domestic or journals published in one of the 15 CEE countries (hereafter CEE journals), and the second group, international or non-CEE journals. The reason for the division of the journals in CEE and non-CEE group is in the assumption that the domestic peer review journals prefer to publish more of local and national research topics in relation to the non-CEE journals. The CEE journals group consists of 13 educational sciences journals from the six out of the 15 CEE countries: Lithuania, Poland and Slovenia by 3, Croatia by 2, and Czech Republic and Serbia by 1 journal, which published share of $48.6 \%$ or 1,163 papers. The group of international educational sciences journals consists predominantly of European journals, with $60 \%$ or 151 . Journals from US, Australia and Canada are followed by the share of 34\%, and the rest were dispersed among worldwide countries. The share of published papers in the group of international journals was $51.4 \%$ or 1,232 papers.

Checking the summaries for the purpose of content analysis showed that the abstracts of 228 or $9.6 \%$ papers do not show any connection between the paper and educational sciences. The research in those cases was conducted on a sample of students or students in some other scientific field and the papers relate to the elaboration of topics in some field of education (e.g., ICT, medicine, economics, geography, history), without an elaboration of the educational process itself. Such papers were excluded from further analysis. The research, therefore, was conducted on a sample of $\mathbf{2 , 1 6 7}$ paper abstracts, $48.2 \%$ (or 1,044 papers) were published in CEE journals, and 51.8\% (or 1,123) in international journals.

The analysed papers were also grouped by the time of publication, divided into four periods. The first period includes papers published from 1996 to 2004 It covers a nine-year period, while the remaining three are divided into three-year periods. The reason for the non-uniformity of the periods is the fact that in the first period only $10 \%$ of the papers were published. Since the year 2004, after the 8 CEE countries became fullfledged members of the European Union, there is an evident increase in the number of published papers. That fact might also have had an impact on the opportunities for publishing papers in international referenced and recognisable journals (Kuźma, 2008; Popov, 2008; Walterová, 2008). Furthermore, all EU candidates countries were obligated to fulfill European Commission request concerning some scientific and education standards.

The other three periods were grouped was follows:

\footnotetext{
${ }^{1}$ Revised Field of Science and Technology (FOS) Classification in the Frascati Manual www.oecd.org/sti/inno/38235147.pdf
} 
- papers published from 2005 to 2007 (9.1\% or 198 of whole sample)

- papers published in the period of 2008 to 2010 (33.0\% or 716 papers) and

- papers published from the period of 2011 to 2013 (47.4\% or 1028 papers).

\section{Data processing and code scheme}

The analysis of abstracts was based on the processing of their content, where each abstract was treated as a single coding unit (event). The coding of the abstracts for the purpose of qualitative content analysis was performed by subject specialist in educational sciences. The coding scheme was prepared according to the literature review (e.g. Osler, 2013; Plomp, 2013; Wubbels, 2016) and tested at the pilot-sample. The following final coding scheme was developed:

1. the main topic of the paper: a) the general educational topic (e.g. development of the model and methods of learning and teaching, pedagogical and didactical theories, teachers or pupils characteristics etc.); b) the specific teaching subject (e.g., mathematics, geography, history, languages, and other)

2. the stage of education: a) early and preschool education; b) primary education; c) secondary education; d) tertiary education; e) lifelong education; f) several stage of education

3. the main thematic orientation of the paper: a) the process and outcomes of learning and teaching (includes learning and teaching, designing education and the curriculum, inclusion of diversity in education, ICT in education, assessment and grading, teaching specific educational content, lifelong education and development); b) organisation and effectiveness (educational institution management, organisation of the systems and institutions, effectiveness of institutions, quality assurance, users of education, innovation, professional career and guidance, education, competences, and other features of the teacher and other educational workers); c) education and society (the effects of education on society and of society on education, the social role of education, educational systems and policies, inequality and segregation)

4. the type of the paper: a) theoretical paper; b) review paper; c) empirical paper; d) presentation; d) other type of paper.

The empirical papers were further analysed according to:

5. the methodological approaches: a) qualitative method, b) a quantitative method; c) a mixed method

6. the manner of collecting data: a) questionnaires, tests, data etc.; b) analysis of documentation, literature, texts etc.; c) interviews and focus groups; d) action research; e) case studies; f) observation; g) quasi-experiments; h) experiments; i) mixed methods

7. the type of the research sample: a) convenience sample; b) representative sample.

All the results are shown at the descriptive level. The hypothesis was tested by calculating the statistical significance of the Chi-square $\left(\chi^{2}\right)$ test using SPSS software.

In order to classify the data in as much detail as possible, each abstract was examined through reading and re-reading according to each specific research question. In order to avoid as 
much as possible the subjectiveness of the process of coding, exact statements of papers' authors (in terms of applied methodology, the purpose of papers etc.) were following. When it was not possible to code aspects of the particular abstract, the category "unknown" was implemented.

\section{Findings and discussion}

\section{The content of educational sciences}

To gain an insight into the research content of educational sciences of 15 CEE countries three thematic categories were created: the main topic of the paper, the stage of education and the main thematic orientation of the paper.

From an analysis of 2,167 abstracts in the field of educational sciences, it follows that most papers cover general educational topics, while slightly over one-third of papers target specific teaching subjects (Table 1). The analysis of specific teaching subjects was found to dominate the papers in geography. That it is not surprising since Slovenian journal Geografija v Soli (259 papers) is covered by the research sample. Maths comes second, followed by various language subjects. Subjects dedicated to nature and biology and technical subjects follow, as well as papers covering medical subjects. Other subjects in the scientific opus of educational sciences are covered significantly less, which is also due to the topical orientation of the journals in which the papers were published.

Table 1. The share of general topics and specific teaching subjects in the CEE educational sciences papers

\begin{tabular}{|lrr|}
\hline Topic & Frequency & Percentage \\
\hline General pedagogic & 1370 & 63.2 \\
Specific teaching & 787 & 36.3 \\
Unknown & 10 & 0.5 \\
Total & $\mathbf{2 , 1 6 7}$ & $\mathbf{1 0 0}$ \\
\hline The share of specific teaching by teaching subject & Frequency & Percentage \\
Geography & 165 & 21.0 \\
Mathematics & 97 & 12.3 \\
Languages & 84 & 10.7 \\
Nature or Biology & 71 & 9.0 \\
Technical subjects & 71 & 9.0 \\
Medical subjects & 70 & 8.9 \\
IT & 57 & 7.2 \\
Chemistry or Physics & 51 & 6.5 \\
Arts (Visual and Music Culture) & 39 & 5.0 \\
Physical and Health Education & 28 & 3.5 \\
Other subjects (religion, didactics, architecture, etc.) & 40 & 5.1 \\
Interdisciplinary (two and more subjects) & 7 & 0.9 \\
Unknown & 7 & 0.9 \\
Total & $\mathbf{7 8 7}$ & $\mathbf{1 0 0}$ \\
\hline
\end{tabular}


Our findings are similar with the results of the analysis of the articles published in International Journal of Instruction from 2008 to 2017 (Eğmir et al., 2017), as well as with the results of other previously conducted researches (e.g. QANU, 2013; Keiner and Hofbauer, 2018).

Table 2. Representation of the stage of education in the CEE educational sciences papers

\begin{tabular}{|lrr|}
\hline Tier of education & Frequency & Percentage \\
\hline Unknown & 763 & 35.2 \\
Tertiary education & 657 & 30.3 \\
Primary education & 306 & 14.1 \\
Secondary education & 236 & 10.9 \\
Early and preschool education & 69 & 3.2 \\
Several stages of education & 71 & 3.3 \\
Lifelong education & 65 & 3.0 \\
Total & $\mathbf{2 , 1 6 7}$ & $\mathbf{1 0 0}$ \\
\hline
\end{tabular}

It was not possible to ascertain from the content of the abstracts of slightly over a third of the published papers to which stage of education they relate, while one third of the published papers were devoted to higher education (Table 2). Papers relating to primary and secondary education follow. Early and preschool education, lifelong education, and a focus on various stages of education are much less represented in published papers. An interesting difference between the analysed papers is that tertiary education receives significantly more attention than other stages of education (especially in the comparison of articles devoted to the life long learning or early and preschool education). That could be connected with the fact that lifelong learning and early childhood education and care has been gaining significant attention and importance within European policies for the past years (Milotay, 2014; Vourien \& Watts, 2013) and better possibilities to gain finance for conducting researches in these areas of educational sciences.

Table 3. The thematic orientation of the papers in the CEE educational sciences papers

\begin{tabular}{|lcc|}
\hline Process and outcomes of learning $(\mathbf{n}=\mathbf{1 3 1 1}$ or 60.5\%) & Frequency & Percentage \\
Process of teaching and learning & 529 & 40.4 \\
ICT in instruction & 286 & 21.8 \\
Curriculum & 208 & 15.9 \\
Assessment & 117 & 8.9 \\
Educational inclusion & 110 & 8.3 \\
Didactic-methodical materials, including textbooks & 61 & 4.7 \\
Total & $\mathbf{1 , 3 1 1}$ & $\mathbf{1 0 0}$ \\
Organisation and effectiveness (n= 594 or 27.4\%) & & \\
Users of education (parents, pupils, and others) & 247 & 41.6 \\
Competences of teachers & 147 & 24.7 \\
Professional development and identity of teachers & 95 & 16.0 \\
Characteristics of the institution (including institution & & 8.8 \\
psychosocial climate, and others) & 52 & \\
\end{tabular}




\begin{tabular}{|lcc|}
\hline $\begin{array}{l}\text { Characteristics of educational workers (positions, opinions, status, and } \\
\text { other) }\end{array}$ & 53 & 8.9 \\
Total & $\mathbf{5 9 4}$ & $\mathbf{1 0 0}$ \\
Education and society $(\mathbf{n}=\mathbf{2 6 2}$ or 12.1\%) & & \\
Social environment & 17 & 6.5 \\
Educational system & 178 & 67.8 \\
Science in society & 67 & 25.7 \\
Total & $\mathbf{2 6 2}$ & $\mathbf{1 0 0}$ \\
\hline
\end{tabular}

Table 3 shows the representation of topics in papers according to the Wubbels division (2016). It follows from the data that most papers are dedicated to the process and outcomes of learning and teaching, while somewhat less than one-third of papers are aimed at organization and effectiveness. At the same time, only slightly over one-tenth of the papers relate to the relationship between education and society. It follows from the data that in the the process and outcomes of learning, themes relating to the teaching process prevail, and one paper in five is devoted to the application of ICT in education. All other topics are represented to a significantly lesser extent (curriculum, valuation, inclusion, didactic and methodical materials). In the group of papers relating to organization and effectiveness, most papers are directed at pupils and their abilities, positions, and mental, social, and physical characteristics. One paper in four is dedicated to the competences of teachers, while other topics are less represented. In the unit science and education, analyses of educational systems prevail, and they consist mostly of analyses of development and change in the system in different periods. Obtained data are in line with the Kwiek's (2012) claim that the communist legacy, but also the post-communist legacy of the first decade of transition period (the 1990s) matters as universities in the region are more teaching-focused than involved in traditional research-based knowledge production. This influence is visible over a longer period of one decade.

In order to gain insight into the changes of the content of scientific production in educational sciences in the countries analysed, the statistical significance of the described characteristics of papers in the four time periods was tested via the Chi-square $\left(\chi^{2}\right)$ test (Table 4$)$.

Table 4. Differences in the content of the CEE educational sciences papers in four time periods

\begin{tabular}{|c|c|c|c|c|c|c|c|c|c|c|}
\hline \multirow{2}{*}{\multicolumn{2}{|c|}{\begin{tabular}{l|r} 
Periods & 199 \\
Topic $\left(\chi^{2}=71.313, p=.000\right)$
\end{tabular}}} & 2004 & \multicolumn{2}{|c|}{ 2005-2007 } & \multicolumn{2}{|c|}{ 2008-2010 } & \multicolumn{2}{|c|}{ 2011-2013 } & \multicolumn{2}{|c|}{ Total } \\
\hline & & & & & & & & & & \\
\hline & $\mathbf{N}$ & $\%$ & $\mathbf{N}$ & $\%$ & $\mathbf{N}$ & $\%$ & $\mathbf{N}$ & $\%$ & $\mathbf{N}$ & $\%$ \\
\hline General pedagogic & 96 & 7.0 & 99 & 7.2 & 481 & $35.1^{*}$ & 694 & $50.7 *$ & 1370 & 100 \\
\hline Specific teaching & 129 & $16.4^{*}$ & 99 & $12.6^{*}$ & 230 & 29.2 & 329 & 41.8 & 787 & 100 \\
\hline Unknown & 0 & 0 & 0 & 0 & 5 & 50 & 5 & 50 & 10 & 100 \\
\hline Total & 225 & 10.4 & 198 & 9.1 & 716 & 33.0 & 1028 & 47.4 & 2,167 & 100 \\
\hline \multicolumn{11}{|c|}{ Stage of education $\left(\chi^{2}=36.650, p=.018\right)$} \\
\hline & $\mathbf{N}$ & $\%$ & $\mathbf{N}$ & $\%$ & $\mathbf{N}$ & $\%$ & $\mathbf{N}$ & $\%$ & $\mathbf{N}$ & $\%$ \\
\hline Early and preschool & 0 & 0 & 3 & 4.3 & 24 & 34.8 & 42 & $60.9^{*}$ & 69 & 100 \\
\hline
\end{tabular}




\begin{tabular}{|c|c|c|c|c|c|c|c|c|c|c|}
\hline Primary & 23 & 7.5 & 24 & 7.8 & 93 & 30.4 & 166 & $54.2^{*}$ & 306 & 100 \\
\hline Secondary & 23 & 9.7 & 19 & 8.1 & 83 & $35.2^{*}$ & 111 & 47.0 & 236 & 100 \\
\hline Tertiary & 89 & $13.5^{*}$ & 63 & 9.6 & 193 & 29.4 & 312 & 47.5 & 657 & 100 \\
\hline Lifelong & 6 & 9.2 & 6 & 9.2 & 22 & 33.8 & 31 & 47.7 & 65 & 100 \\
\hline Several stages & 8 & 11.3 & 6 & 8.5 & 22 & 31.0 & 35 & $49.3 *$ & 71 & 100 \\
\hline Unknown & 76 & 10.0 & 77 & $10.1 *$ & 279 & $36.5^{*}$ & 331 & 43.4 & 763 & 100 \\
\hline Total & 225 & 10.4 & 198 & 9.1 & 716 & 33.0 & 1028 & 47.4 & 2,167 & 100 \\
\hline \multicolumn{11}{|c|}{ Thematic orientation $\left(\chi^{2}=41.199, p=.000\right)$} \\
\hline & $\mathbf{N}$ & $\%$ & $\mathbf{N}$ & $\%$ & $\mathbf{N}$ & $\%$ & $\mathbf{N}$ & $\%$ & $\mathbf{N}$ & $\%$ \\
\hline $\begin{array}{l}\text { Process and } \\
\text { outcomes of learning } \\
\text { and teaching }\end{array}$ & 170 & $13.0^{*}$ & 123 & 9.4 & 423 & 32.3 & 595 & 45.4 & 1311 & 100 \\
\hline $\begin{array}{l}\text { Organisation and } \\
\text { effectiveness }\end{array}$ & 28 & 4.7 & 41 & 6.9 & 213 & $35.9^{*}$ & 312 & $52.5^{*}$ & 594 & 100 \\
\hline $\begin{array}{l}\text { Education and } \\
\text { society }\end{array}$ & 27 & 10.3 & 34 & $13.0^{*}$ & 79 & 30.3 & 122 & 46.4 & 262 & 100 \\
\hline Total & 225 & 10.4 & 198 & 9.1 & 716 & 33.0 & 1028 & 47.4 & 2,167 & 100 \\
\hline
\end{tabular}

The analysis of the dynamic of research activity during the four periods shows that the productivity of CEE scientists in educational science has increased from 2008 on and that the most productive period began in year 2011. The significant increase in the number of papers after 2008 could be explained with the fact that Scopus started to index a large number of CEE educational science journals. Generally, the productivity of CEE scholars increased in the in the period from 2011 to 2013. Based on the value of the $\chi^{2}$ test, it is possible to conclude that over time all content-related characteristics of the papers experienced statistically significant changes. The greatest changes in the scientific opus analysed occurred in the main topic of the papers into general or specific teaching subjects because there has recently been a growing number of papers in educational sciences that are oriented towards pedagogic topics, started with year 2008. An increasing number of papers in the field of early and preschool, as well as in primary education occurred in the period from 2011 to 2013. The number of papers that include several stages of education (e.g. longitudinal research) increased also in that period. Bigger interest in research of secondary education appears in the period from 2008 to 2010 .

In terms of the main themes of the papers, the number of papers dealing with organization and effectiveness is rising from 2008 onwards. In previous periods has increased the number of papers dealing with process and outcomes of learning and teaching (until year 2004) and education and society (from year 2005). The identified general and specific teaching subject themes of analysed papers illustrate the complexity of education as a phenomenon, richness of scientific production in educational science that allow the specialisation and professionalisation of research in a given domain, indicating the evolution of education as scientific discipline (Hofstetter and Schneuwly, 2002).

Testing the differences in the content of papers analysed in view of the journal in which they were published showed that there were no statistically significant differences in the content of papers published in CEE journals or other international journals. Absence of difference in the 
content of published papers in CEE and international journals might be the consequence of the process of Europeanisation of educational systems in CEE countries that is most visible in the area of higher education (Antunes, 2016; Dakowska, 2017). Bearing in mind that in the times of socialist governments, publishing in renowned foreign journals was virtually inconceivable of (Grančay et al., 2017).

The presentation of findings from our research regarding the content analysis demonstrate clearly that analysed educational sciences papers of CEE scholars covers wide range of different content, with prevalent orientation in general pedagogical topics (especially themes about process and outcomes of teaching and learning).

Diversity of dominant content and thematic orientation is more visible after year 2008. This might be due to the large increase in the number of published papers, but also due to the interest of CEE researches in different aspects of education and educational researches. The described trends in the content of educational sciences in CEE countries will probably result in an increase in the total quantity of papers directed to the education and society published in the near future since they are still underrepresented in the total scientific opus in educational sciences.

\section{The methodological approaches of educational sciences research}

In order to gain insight into the methodological approach used by scientists from European post-socialistic countries in educational sciences research, the abstracts were analysed in view of the type of paper (whether it is theoretical, a review paper, research paper or presentation, essay, discussion, etc.). The distribution of papers based on this criterion is shown in Figure 1.

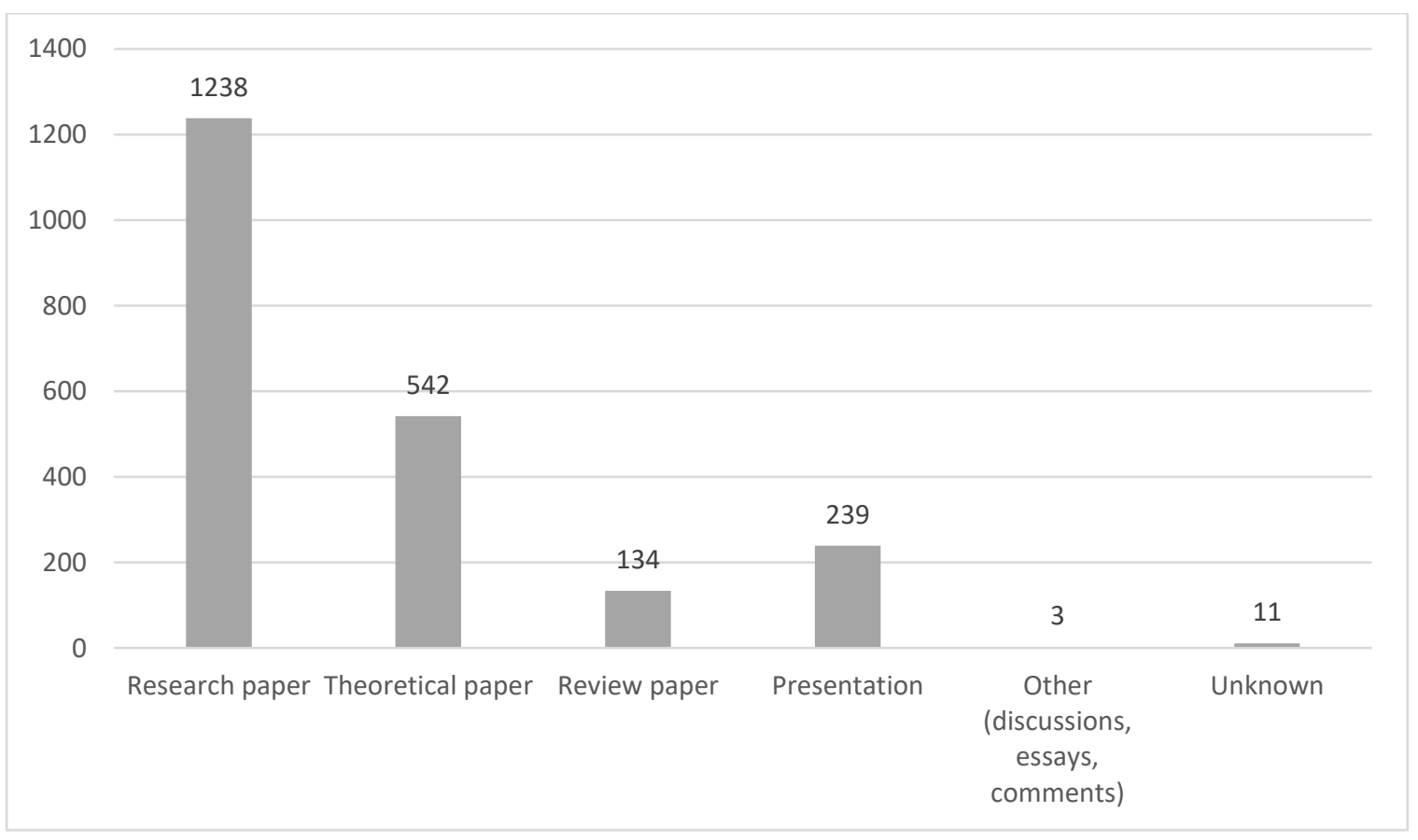

Figure 1. The types of the CEE educational sciences papers $(n=2,167)$ 
It is clearly visible that research papers prevail. They account for more than half of all papers published (57.7\%), which means that a major part of the scientific activity is oriented towards original scientific papers based on empirical research. One-quarter $(25 \%)$ are of a theoretical character, which indicate certain interest in theoretical analyses from various aspects of educational sciences (e.g., descriptions of the characteristics of education in certain countries or historical periods, elaboration of various teaching and learning methods, theories of learning and teaching, possibilities for using ICT in instruction, etc.). Slightly over one in ten papers (11\%) relate to presentations of the curricula, didactic models in subjects, interdisciplinary or field learning and teaching, learning methods for individual subjects, etc. Reviews account for $6 \%$ of the total number of papers published and they relate to the presentation of research in certain fields of education (e.g., changes in educational systems in certain countries, risk analyses in educational systems of two or more countries, differences in educational achievements, possibilities for using ICT in instruction, the effectiveness of various methods of learning and teaching, etc.). The share of other types of papers is negligible, and there are also a few abstracts that did not allow for identification of the type of paper concerned.

Of the total of 2,167 papers published in the field of educational sciences in the period from 1996 to 2013, scientists from 15 European post-socialistic countries published $57.2 \%$ (or 1,238) scientific papers based on original empirical research. In that sample of papers, research based on the quantitative method prevails $(54.8 \%)$, while one-quarter of research is conducted through the use of qualitative methodological approach (25\%). Less than one-tenth of papers $(8.6 \%)$ include a combination of qualitative and quantitative methods (mixed method). It was not possible to conclude which method of research was presented in the papers in $11.6 \%$ of the abstracts (Figure 2).

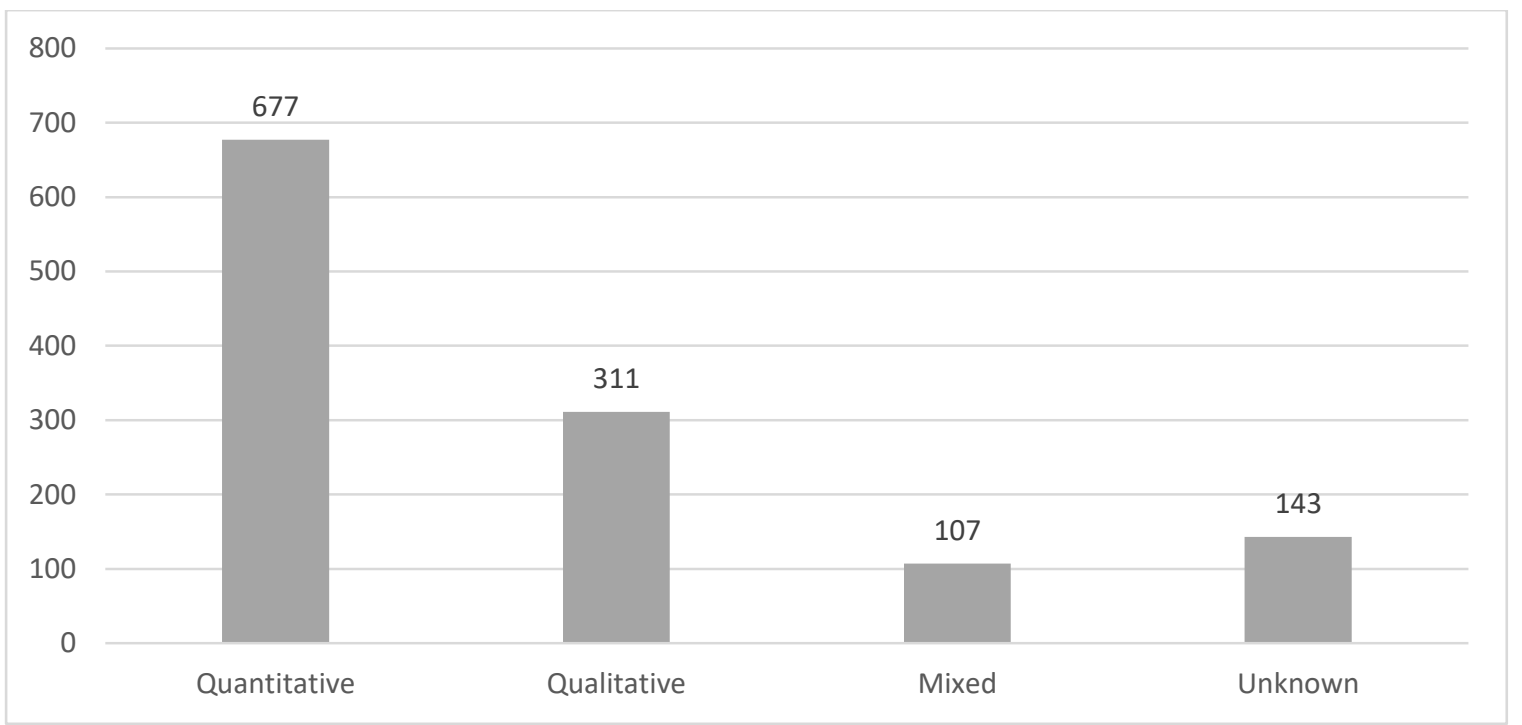

Figure 2. The methods used in the research in the CEE educational sciences papers $(\mathrm{n}=$ $1,238)$ 
These results are in line with the analysis of the studies published in International Journal of Instruction from 2008 to March 2017, which showed that studies in the field of education mostly employ quantitative methods and prevalence of scales and the data collection as research's tools. However, in that analysis purposive or random sampling techniques were dominant (Eğmir et al., 2017).

In view of the prevalence of research based on the quantitative method, it is not surprising that research in which data were collected via questionnaires, scales, polls, tests of knowledge or statistical and other data (such as the results of PISA) outside the research itself are significantly represented. Quasi-experiments and analyses of the content of documents and literature are also somewhat more significant, while all the other methods in the sample are represented to a significantly lesser extent. Only one-quarter of the research was conducted on a representative sample $(24.5 \%)$, while no conclusion concerning this issue could be drawn from the abstracts in $41.2 \%$ of cases (Table 5). Assums et al. (2011) also found that the presence of quasi-experimental designs are not very often used in 18 social science journals that they investigated. Ertl et al. (2013) compared six leading journals of education in Germany and England in period from 2001 to 2009. They found a higher proportion of nonempirical articles (often using a historical approach) in the three German journals and a higher proportion of articles drawing on primary empirical data in the three English journals.

Table 5. The manner of collecting data and the type of the research sample in the CEE educational sciences papers

\begin{tabular}{|lrr|}
\hline Manner of collecting data & Frequency & Percentage \\
Questionnaires, tests, data etc. & 484 & 39.1 \\
Analysis of documentation, literature, texts etc. & 127 & 10.3 \\
Interviews and focus groups & 60 & 4.8 \\
Action research & 23 & 1.9 \\
Case studies & 38 & 3.1 \\
Observation & 7 & 0.6 \\
Quasi-experiments & 160 & 12.9 \\
Experiments & 106 & 8.6 \\
Mixed methods & 74 & 6.0 \\
Unknown & 159 & 12.7 \\
Total & $\mathbf{1 , 2 3 8}$ & $\mathbf{1 0 0}$ \\
Type of the research sample & & \\
Convenience & 434 & 35.1 \\
Representative & 299 & 24.2 \\
Unknown & 505 & 40.7 \\
Total & $\mathbf{1 , 2 3 8}$ & $\mathbf{1 0 0}$ \\
\hline
\end{tabular}

Data on the research sample were visible in $89.1 \%(1,102)$ of the abstracts. According to them, the most frequent sample of respondents included children or pupils, and students. 
They account for more than half of the respondents (54\%). They are followed by teachers (on their own or in combination with other educational workers) who are the source of data in $17.1 \%$ of all the scientific research. The share of all other sources of data (e.g. parents, experts in the field of the research, courses and study programmes etc.) is under $10 \%$. In general, research is usually based on only one group of respondents $(88.3 \%)$, while research in which hypotheses are examined on two and more of sources of data (e.g. teachers and pupils, teachers and parents) is significantly rarer $(11.3 \%)$. The prevalence of convenience researches is highlighted in previous researches and analysis (e.g. Walterová, 2008; Antonowicz et al., 2017).

Table 6 shows whether or not changes occurred in the methodological approaches of educational sciences research prepared by CEE scholars over time.

Table 6. Differences in the methods used in scientific research in the CEE educational sciences papers in the course of four periods

\begin{tabular}{|c|c|c|c|c|c|c|c|c|c|c|}
\hline Periods & \multicolumn{2}{|c|}{ 1996-2004 } & \multicolumn{2}{|c|}{ 2005-2007 } & \multicolumn{2}{|c|}{ 2008-2010 } & \multicolumn{2}{|c|}{ 2011-2013 } & \multicolumn{2}{|c|}{ Total } \\
\hline \multicolumn{11}{|c|}{ Type of paper $\left(\chi^{2}=150.094, p=.000\right)$} \\
\hline & $\mathbf{N}$ & $\%$ & $\mathbf{N}$ & $\%$ & $\mathbf{N}$ & $\%$ & $\mathbf{N}$ & $\%$ & $\mathbf{N}$ & $\%$ \\
\hline Research paper & 70 & 5.7 & 83 & 6.7 & 411 & 33.2 & 674 & $54.4 *$ & 1238 & 100 \\
\hline Review paper & 18 & $13.4^{*}$ & 15 & $11.2^{*}$ & 46 & 34.3 & 55 & 41.0 & 134 & 100 \\
\hline Theoretical paper & 75 & $13.8^{*}$ & 62 & $11.4^{*}$ & 183 & 33.8 & 222 & 41.0 & 542 & 100 \\
\hline Presentation & 61 & $25.5^{*}$ & 37 & $15.5^{*}$ & 70 & 29.3 & 71 & 29.7 & 239 & 100 \\
\hline Other and unknown & 1 & 2.2 & 1 & 2.2 & 6 & $42.8^{*}$ & 6 & 42.8 & 14 & 100 \\
\hline Total & 225 & 10.4 & 198 & 9.1 & 716 & 33.0 & 1028 & 47.4 & 2167 & 100 \\
\hline \multicolumn{11}{|c|}{ Research method $\left(\chi^{2}=18,989, p=.025\right)$} \\
\hline & $\mathbf{N}$ & $\%$ & $\mathbf{N}$ & $\%$ & $\mathbf{N}$ & $\%$ & $\mathbf{N}$ & $\%$ & $\mathbf{N}$ & $\%$ \\
\hline Quantitative & 39 & 5.8 & 41 & 6.1 & 197 & 29.1 & 400 & $59.1 *$ & 677 & 100 \\
\hline Qualitative & 17 & 5.5 & 19 & 6.1 & 115 & $37.0^{*}$ & 160 & 51.4 & 311 & 100 \\
\hline Mixed & 6 & 5.6 & 12 & $11.2 *$ & 40 & $37.4^{*}$ & 49 & 45.8 & 107 & 100 \\
\hline Unknown & 8 & 5.6 & 11 & 7.7 & 59 & $41.3^{*}$ & 65 & 45.5 & 143 & 100 \\
\hline Total & 70 & 5.7 & 83 & 6.7 & 411 & 33.2 & 674 & 54.4 & 1238 & 100 \\
\hline \multicolumn{11}{|c|}{ Research sample $\left(\chi^{2}=15.045, p=.020\right)$} \\
\hline & $\mathbf{N}$ & $\%$ & $\mathbf{N}$ & $\%$ & $\mathbf{N}$ & $\%$ & $\mathbf{N}$ & $\%$ & $\mathbf{N}$ & $\%$ \\
\hline Convenience & 31 & $7.1^{*}$ & 25 & 5.8 & 122 & 28.1 & 256 & $59.0 *$ & 434 & 100 \\
\hline Representative & 12 & 4.0 & 25 & $8.4^{*}$ & 97 & 32.4 & 165 & 55.2 & 299 & 100 \\
\hline Unknown & 27 & 5.4 & 33 & 6.6 & 192 & $37.8 *$ & 251 & 50.2 & 502 & 100 \\
\hline Total & 70 & 5.7 & 83 & 6.7 & 411 & 33.2 & 674 & 54.4 & 1238 & 100 \\
\hline
\end{tabular}

It clearly follows from the results displayed that in the period before 2008, presentation, review, and theoretical papers in educational sciences prevailed in educational institutions. 
On the other hand, from year 2011, there are significantly more empirical papers in the CEE educational sciences. Çiftçi et al. (2016) also concluded that the highest number of empirical articles were published in year 2012 in the field of educational sciences and teacher education in Turkey (in period from 2005 to 2014). Differences in the methods used in scientific research in educational sciences over time are statistically significant but less pronounced than when it comes to the content and methods used in all papers published in the period analysed. There are no differences in relation to the periods of publication of papers and the size of the sample and sources of data on which the research is based, but differences do exist in the case of the applied research method and the type of sample. In the earliest analysed period, scientific papers based on the qualitative methodology and convenience research samples are statistically more significant in terms of prevalence, while the period from 2008 to 2010 is characterised by a higher representation of the qualitative methodology and combined methodology based on representative samples. In the latter period, abstracts from which it is not possible to recognise the research method or the sample on which it was conducted also stand out. The period from 2011 to 2013 is characterised by papers using quantitative methods and representative samples.

An analysis of the differences in the methods used in the research in the field of educational sciences in view of whether they were published in CEE or international journals did not yield any statistically significant differences. The lack of differences in the methods of papers published in CEE and international journals indicates the globalisation of educational sciences that transcends regional borders (Lindblad, 2014; Dobbins and Kwiek, 2017). Also, the lack of significant differences among journals in the sample, illustrate a comparable quality of CEE educational journals and international journals. If there is a significant difference in the visibility of these journals measured by the number and type of citations obtained, it should be determined by bibliometric analyses.

\section{Conclusion}

This research is one of the initial with the purpose to gain insight into the state of research in educational sciences in Central and Eastern Europe (CEE) countries. Scientists from 15 European post-socialistic countries published 2,167 papers in 252 journals in the field of educational sciences, as covered in the Scopus database in the period from 1996 to 2013. In this research, we have analysed the abstracts of those papers in order to understand the specificity of educational subject and content issues, methodological approaches used in the research, dynamics, and specificity of the development of this scientific discipline in the region of Central and Eastern Europe. It was found that the field of educational sciences in the analysed sample has changed over time in terms of quantity, content, and methods, becoming more expansive and diverse, which is equally evident from papers published in CEE journals as well as in international journals.

The changes manifest themselves first and foremost in the great expansion of published papers that increased five-fold from 2008 to 2013. The significant increase in the number of papers after 2008 could be explained by indexing in Scopus of a large number of CEE 
educational science journals, as well as the fact that most countries from the sample became the European Union member states in 2004, which might have had a direct impact on the opportunities for publishing papers in international referenced and recognisable journals.

Although educational sciences are still mostly directed at the learning and teaching process and outcomes, especially in higher education, as of late there has been a trend of expanding topics to relations between society and education, and organisation and effectiveness. Early and preschool education, as well as lifelong education, is still relatively neglected in the opus of educational sciences, as is the case with different teaching subjects (with the exception of geography, mathematics, and languages).

Although slightly over one half of the published papers are based on original scientific work, in the field of educational sciences other types of paper (especially theoretical papers, review papers, and presentations) are relatively frequent. The predominant focus on the quantitative data collection methods, primarily by testing opinions, positions, competences, abilities and other characteristics of teachers, children, pupils and students, is a feature of contemporary research in educational sciences. All other parts of the educational process are less represented, as we rarely encounter in the research representative samples that would allow for valid generalisations of the research findings. In the research opus of educational sciences, convenience samples prevail. Research that includes various methods and various groups of respondents is particularly scarce, although this would give a better quality insight into the research field.

Judging by the findings of this research, changes in education and educational sciences are still taking place today, and they are becoming more diverse and more universal, crossing national, regional, and other geographical borders and areas. According to Grimaldi (2015, p. 59) "... in Europe we are undoubtedly living a troubling present where education and research policies are veering towards instrumental ends and spaces of autonomy for European Educational Research are becoming increasingly narrow. At the same time, we need to recognize that we, as educational researchers, live, explore and co-shape our field".

Integrating CEE in a stable European space for education research (Lawn, 2014) is unavoidable. But, according to Kwiek $(2012$, p. 123) “... the transformation of universities may take much longer, and the gradual convergence of both higher education and research systems in the two parts of Europe (West Europe and CEE) cannot be taken for granted without thoughtful changes in both university funding (in terms of both modes and levels) and governance. Central European universities desperately struggle to remain in the global academic centre, but their gradual decline to the academic peripheries cannot be excluded".

Even though it is obvious that the field of educational sciences in 15 European postsocialistic countries has changed over times in terms of quantity and subject issues, there is still room for the further improvement of its content. This improvement should involve more interdisciplinary researches that compare different teaching subject, as well as all specific themes that belong to the explanation of the connection between education and society.

\section{Limitations of the research}


Although this research was conducted on a sample of abstracts from all papers published in the field of educational sciences in journals indexed in the Scopus database in the period from 1996 to 2013, it does not include the totality of scientific production in 15 post-socialist countries in the observed period, since books and papers published in other journals were not analysed. Further, the data are based on the content analysis of the abstracts, among which there were a certain number that, in view of their content, did not allow for the categorisation of the papers based on the selected variables. Further, this paper does not have a comparative component that would include a comparison with other, western European and nonEuropean, authors. Therefore, the results obtained may justifiably be interpreted only as an overview of the situation of educational sciences in the countries of East and Central Europe, without generalisation in terms of the state of educational sciences on the global scale.

\section{Funding Acknowledgments}

This work was supported by the Croatian Science Foundation (grant number IP-2014-099351

\section{References:}

Abadal E, Melero R and Rodrigues R et al. (2015) Spanish Scholarly Journals in WoS and Scopus: The Impact of Open Access. Journal of Scholarly Publishing 47(1): 77-96.

Aman V and Botte A (2017) A bibliometric view on the internationalization of European educational research. European Educational Research Journal 16(6): 843-868.

Antonowicz D, Kohoutek J, Pinheiro R and Hladchenko, M (2017) The roads of 'excellence' in Central and Eastern Europe. European Educational Research Journal, 16(5): 547-567.

Antunes F (2016) Economising education: From the silent revolution to rethinking education. A new moment of Europeanisation of education? European Educational Research Journal 15(4): 410-427.

Archambault É, Campbell D and Gingras Y et al. (2009) Comparing bibliometric statistics obtained from the Web of Science and Scopus. Journal of the American Society for Information Science and Technology 60(7): 1320-1326.

Aussems MCE, Boomsma A and Snijders TAB (2011) The Use of Quasi-experiments in the Social Sciences: A Content Analysis. Quality \& Quantity International Journal of Methodology 45: 21-42.

Bar-Ilan J (2007) Which h-index? A comparison of WoS, Scopus and Google Scholar. Scientometrics 74(2): 257-271.

Baranović B, Domović V and Vizek Vidović V (2013) Promjene i razvojni pravci u suvremenom obrazovanju. In: Milanović D, Bežen A and Domović V (eds.) Metodike $u$ suvremenom odgojno-obrazovnom sustavu. Zagreb: Akademija odgojno-obrazovnih znanosti Hrvatske, pp. 7-25.

Bellmann J and Su H (2017) Democracy and Bildung/Erziehung-Towards a Universal Theory of Education. Education Science 7(5): 1-11.

Berliner D (2002) Comment: Educational Research: The Hardest Science of All. Educational Researcher 31(8): 18-20. 
Chadegani A, Salehi H and Yunus MD, Farhadi M. and Ale Ebrahim N (2013) A Comparison between Two Main Academic Literature Collections: Web of Science and Scopus Databases. Asian Social Science 9(5): 18-26.

Çiftçi ŞK, Danişman Ş, Yalçin M, Tosuntaş ŞB, Ay Y, Sölpük N and Karada E (2016) Map of Scientific Publication in the Field of Educational Sciences and Teacher Eduacation in Turkey: A Bibliometric Study. Educational Sciences: Theory \& Practice 16(4): 1097-1123.

Dakowska D (2017). Competitive universities? The impact of international and European trends on academic institutions in the 'New Europe'. European Educational Research Journal 16(5):588-604.

De Corte E (2018) Educational Sciences: A Crossroad for Dialogue among Disciplines. European Review 26(2): 262-271.

Dobbins M and Kwiek M (2017) Europeanisation and globalisation in higher education in Central and Eastern Europe: 25 years of changes revisited (1990-2015). European Educational Research Journal 16(5): 519-528.

Dobbins M (2017) Exploring higher education governance in Poland and Romania: Reconvergence after divergence? European Educational Research Journal 16 (5): 684704.

Eğmir E, Erdem C and Koçyiğit M (2017) Trends in Educational Research: A Content Analysis of the Studies Published in International Journal of Instruction. International Journal of Instruction 10(3): 277-294.

Elken M and Wollscheid S (2016) The Relationship between Research and Education: Typologies and Indicators: A Literature Review. Report 2016:8, Oslo: Nordic Institute for Studies in Innovation, Research and Education (NIFU), Available at: https://brage.bibsys.no/xmlui/bitstream/id/ 418864/NIFUreport2016-8.pdf (accessed 12 June 2017).

Ertl H, Zierer K, Phillips D and Tippelt R (2013) Analysis of Academic Journals in Education: a comparison of publication patterns in England and Germany. Research in Comparative and International Education 8(1):1-16.

Falagas M, Pitsouni E, Malietzis G and Pappas G (2008) Comparison of PubMed, Scopus, Web of Science, and Google Scholar: strengths and weaknesses. The FASEB Journal 22(2): 338-342

Fritzell C (2006) On the Reconstruction of Educational Science. Educational Philosophy and Theory 38(2): 129-143.

Furlong J and Lawn, M, Eds. (2010) Disciplines of Education: Their Role in the Future of Education Research. Abingdon: Routledge.

García J, Rodriguez-Sánchez R and Fdez-Valdivia J (2011) Ranking of the subject areas of Scopus. Journal of the American Society for Information Science and Technology 62(10): 2013-2023.

Grančay M, Vveinhardt J and Šumilo E E (2017) Publish or perish: how Central and Eastern European economists have dealt with the ever-increasing academic publishing requirements 2000-2015. Scientometrics 111(3): 1813-1837. 
Grimaldi E (2015) What future for educational research in Europe? Political, epistemological and ethical challenges. European Educational Research Journal 14(1): 49-55.

Hofstetter R and Schneuwly B (2002) Institutionalisation of Educational Sciences and the Dynamics of Their Development. European Educational Research Journal 1(1): 3-26.

Kalantzis M and Cope B (2012) New Learning: Elements of Science of Education. (2 ${ }^{\text {nd }}$ ed.). Melbourne: Vic. Cambridge University Press.

Keiner E and Hofbauer S (2018) EERA and its European Conferences on Educational Research: A Patchwork of Research on European Educational Research. European Educational Research Journal 13(4): 504-518.

Kováts G, Heidrich B and Chandler N (2017) The pendulum strikes back? An analysis of the evolution of Hungarian higher education governance and organisational structures since the 1980s. European Educational Research Journal 16(5): 568-587.

Kushnir I (2016) The role of the Bologna Process in defining Europe. European Educational Research Journal 15(6): 664-675.

Kuźma J (2008) The Polish Comparative Education Society. In: Masemann V, Bray M and Manzon M (eds.) Common Interests, Uncommon Goals: History of the World Council of Comparative Education Societies and Its Members. Hong Kong: Comaprative Education Research Centre, pp. 256-267.

Kwiek M (2017) A generational divide in the academic profession: A mixed quantitative and qualitative approach to the Polish case. European Educational Research Journal 16(5): 645-669.

Kwiek M (2012) Universities and Knowledge Production in Central Europe. European Educational Research Journal 11 (1): 111-125.

Lawn M (2014) Transnational lives in European Educational Research. European Educational Research Journal 13 (4) : 481-492.

Lindblad S (2014) Observations on European Education and Educational Research: The European Educational Research Journal at work, 2002-2014. European Educational Research Journal 13(4): 493-503.

Little SG, Akin-Little A and Lloyd K (2011) Content Analysis of School Psychology International, 1990-2011: An Analysis of Trends and Compatibility with the NASP Practice Model. School Psychology International 32(6): 569-591.

Manzon M and Bray M (2008) Comparing the Comparers: Patterns, Themes and Interpretations. In: Masemann V, Bray M and Manzon M (eds) Common Interests, Uncommon Goals: History of the World Council of Comparative Education Societies and Its Members. Hong Kong: Comaprative Education Research Centre, pp. 336-363.

Manzon, M (2018) Comparative education histories: a postscript. Comparative Education, doi: 10.1080/03050068.2018.1420511

Milotay N (2014) Razvoj politika ranog i predškolskog odgoja i obrazovanja od '90-tih u EU. Djeca u Europi: zajednička publikacija mreže europskih časopisa 6(11): 4-7.

Moed H, Aisati M and Plume A (2012) Studying scientific migration in Scopus. Scientometrics 94(3): 929-942. 
Németh A (2017) The Development's Phases of Educational Sciences as an Academic Discipline in Hungary in the First Half of the $20^{\text {th }}$ Century. Foro de Educación 15(22): $1-23$.

Nolen AL (2009) The Content of Educational Psychology: An Analysis of Top Ranked Journals from 2003 through 2007. Educational Psychology Review 21: 279-289.

OECD (2007). Revised Field of science and technology (FOS) Classification in the Frascati Manual - Working Party of National Experts on Science and Technology Indicators. Paris: OECD Publishing, Directorate for Science, Technology and Industry, Available at: https://www.oecd.org/science/inno/38235147.pdf (accessed 10 June 2017).

Osler JE (2013) The Psychometrics of Educational Science: Designing Trichotomous Inventive Investigative Instruments for Qualitative and Quantitative Inquiry. Journal on School Educational Technology 8(3): 15-22.

Pastuović N (2012). Obrazovanje i razvoj: Kako obrazovanje razvija ljude i mijenja društvo, a kako društvo djeluje na obrazovanje. Zagreb: Institut za društvena istraživanja u Zagrebu and Centar za istraživanje i razvoj obrazovanja.

Plomp T (2013) Educational Design Research: An Introduction. In: Plomp T and Nieveen N (eds.), Educational Design Research. Enschede: Netherlands Institute for Curriculum Development, pp. 10-51.

Popov N (2008) The Bulgarian Comparative Education Society. In: Masemann V, Bray $\mathrm{M}$ and Manzon M (eds) Common Interests, Uncommon Goals: Historie of the World Cuncil of Comparative Education Societies and its Members. Hong Kong: Comparative Education Research Centre, pp. 268-277.

Prasad BD (2008) Content Analysis: A Method in Social Science Research. In: Lal Das DK and Bhaskaren V (Eds.) Research methods for Social Work New Delhi: Rawat, pp 173-193.

Proteasa V, Andreescu L and Curaj A (2017) Differentiation and academic control over policy in Central and Eastern Europe: The case of Romania. European Educational Research Journal, 16(5): 605-625.

Quality Assurance Netherlands Universities, QANU (2013) Research Review Pedagogics and Education Science. Utrecht: QANU, Available at: https://www.rug.nl/aboutus/where-do-we-stand/quality-assurance/pdf/5-pedagogics.pdf (accessed 30 October 2018).

Radó P (2011) Regional Educational Performance Patterns in Europe. C.E.P.S. Journal 1(3): 11-29.

Tarlea S (2017) Higher education governance in Central and Eastern Europe: A perspective on Hungary and Poland. European Educational Research Journal 16(5): 670-683.

Terhart E (2017) Interdisciplinary research on education and its disciplines: Processes of change and lines of conflict in unstable academic expert cultures: Germany as an example.European Educational Research Journal 16(6): 921-936.

Vuorinen R and Watts AG (2013) Razvoj politike cjeloživotnog profesionalnog usmjeravanja: Europski priručnik sa smjernicama za oblikovanje politika cjeloživotnog profesionalnog usmjeravanja. Europska mreža politika cjeloživotnog profesionalnog 
usmjeravanja (ELGPN). Availabe at: http://www.hzz.hr/UserDocsImages/ELGPN (accessed 7 November 2017).

Walterová E (2008) Comparative Education Section of the Czech Pedagogical Society. In: Masemann V, Bray M and Manzon M (eds) Common Interests, Uncommon Goals: Historie of the World Cuncil of Comparative Education Societies and its Members. Hong Kong: Comaprative Education Research Centre, pp. 256-267.

Wubbels T (2016) Educational Sciences in the Netherlands: State of Affairs and Challenges. Erzieungwisswnschaft 27(52): 55-68. 